Harmoni, Ratih, Purwanti, dan Setiawan: Kebutuhan dan Faktor Kontekstual...

\title{
Kebutuhan Dan Faktor Kontekstual Komunikasi CSR Berbasis Web Pada Perusahaan Tambang Di Indonesia
}

\author{
${ }^{1}$ Ati Harmoni, ${ }^{2}$ Sri Wulan Windu Ratih, ${ }^{3}$ Purwanti, ${ }^{4}$ Budi Setiawan \\ ${ }^{1}$ Jurusan Manajemen Fakultas Ekonomi, ${ }^{2,4}$ Jurusan Teknik Informatika Fakultas \\ Teknologi Industri, ${ }^{3}$ Jurusan Sistem Informasi Fakultas Ilmu Komputer dan TI \\ Universitas Gunadarma \\ ati@staff.gunadarma.ac.id
}

\begin{abstract}
Abstrak: Komunikasi CSR berbasis web didasarkan pada kebutuhan manajemen untuk berdialog dengan pemangku kepentingan yang beragam, internal maupun eksternal perusahaan. Tujuan penelitian ini adalah untuk mengetahui pandangan manajemen atas kebutuhan komunikasi CSR berbasis web. Wawancara dilakukan kepada personel kunci dari 3 perusahaan tambang terkemuka di Indonesia yang mempunyai web resmi dan telah melaksanakan program CSR. Kebutuhan manajemen kemudian dinilai dengan menggunakan kerangka Media Richness Theory. Hasil wawancara menunjukkan bahwa ada faktor yang dipertimbangkan oleh manajemen untuk mengungkapkan informasi CSR di web. Kebutuhan manajemen atas komunikasi CSR berbasis web yang kritikal atau nonkritikal memengaruhi tingkat penggunaan fitur web yang sesuai. Kebutuhan komunikasi yang dianggap kritikal akan menyebabkan pemakaian fitur web ekstensif atau moderat dan sebaliknya apabila manajemen menganggap kebutuhan komunikasi berbasis web adalah non-kritikal maka penggunaan fitur web terbatas.
\end{abstract}

Kata kunci: komunikasi CSR, web resmi, Media Richness Theory, perusahaan tambang

Abstract: Web-based CSR communications are based on management's need to have dialogue with various stakeholders of the company, internal and external. The purpose of this research is to know the management's view on the needs of web-based CSR communication. Interviews were conducted to key personnel from 3 leading mining companies in Indonesia who have an official web and have implemented CSR program. Management needs are then assessed using the framework of Media Richness Theory. Interview results show that there are factors that management considers to disclose CSR information on the web. Critical or non-critical the need ofmanagement for web-based CSR communications affects the appropriate level of use of web features. Communication needs that are considered critical will lead to the use of extensive web features or moderate and vice versa if management considers the need for web-based communication is non-critical then the use of web features is limited.

Keywords: CSR communications, official web, Media Richness Theory, mining companies 
Harmoni, Ratih, Purwanti, dan Setiawan: Kebutuhan dan Faktor Kontekstual...

\section{PENDAHULUAN}

Berdasarkan survey yang dilakukan pada Desember 2007 hingga November 2008, $62 \%$ perusahaan publik yang terdaftar di Bursa Efek Indonesia yang telah memiliki web untuk mempublikasikan informasi finansial dan non finansialnya (Almalia, 2009). Sementara itu, penelitian oleh Harmoni (2011) mengungkapkan bahwa semua perusahaan yang termasuk dalam Indeks Bisnis-27 telah mempunyai web resmi yang memuat informasi tentang CSR.

Penelitian yang lebih luas menunjukkan bahwa perusahaan di seluruh dunia menggunakan web perusahaan untuk menunjukkan perilaku CSR mereka (Maignan \& Ralston, 2002; SustainAbility/UNEP, 2001, 2004), termasuk oleh perusahaan tambang di Indonesia (Harmoni, 2010). Web menjadi media yang masuk akal bagi perusahaan untuk menunjukkan perilaku CSRnya (Esrock \& Leichty, 2000), terutama di negara dengan penggunaan Internet yang tinggi. Beberapa literatur lainnya juga telah membahas komunikasi isu-isu CSR melalui web perusahaan (Harmoni, 2010, 2009; Sustainability/UNEP, 2001; Maignan \& Ralston, 2002; Cormier \& Magnan, 2003; Adams \& Frost, 2004; Campbell, 2004; Unerman \& Bennett, 2004; Frost, Jones, Loftus, \& Van Der Laan, 2005), tetapi pemahaman mendalam tentang penggunaan potensi web untuk mengomunikasikan isu-isu CSR kepada pemangku kepentingan masih kurang. Sebagian besar literatur tersebut terutama telah menyediakan ikhtisar deskriptif dan umum tentang penggunaan web untuk penyampaian informasi CSR tetapi belum menggali secara mendalam kontribusi kontribusi penggunaan web sebagai media komunikasi CSR. Jadi, diperlukan penelitian yang dapat mengungkapkan faktor-faktor yang memengaruhi sejauh mana web dimanfaatkan untuk komunikasi CSR dalam konteks tertentu.

Tulisan ini bertujuan untuk mengungkapkan pandangan manajemen atas komunikasi berbasis web pada perusahaan tambang di Indonesia. Tulisan akan dibagi menjadi 5 bagian. Bagian pertama pendahuluan, bagian kedua mengulas secara singkat landasan teori yang digunakan sedangkan bagian ketiga menguraikan metode penelitian yang dipakai. Bagian keempat menampilkan hasil dan pembahasan. Bagian kelima merupakan penutup dari tulisan ini yang berisi kesimpulan dan saran bagi penelitian berikutnya.

\section{KAJIAN TEORI}

Komunikasi CSR melalui web perusahaan adalah saluran yang diperhitungkan oleh perusahaan. Penggunaan web resmi perusahaan untuk memengaruhi opini publik pada isu tertentu punya potensi yang sangat besar (Esrock \& Leichty, 1998). Adanya kemungkinan interaktivitas antara masyarakat dan organisasi adalah isu yang sangat relevan. Interaktivitas adalah karakteristik utama internet, dan menjadi subyek dalam 
Harmoni, Ratih, Purwanti, dan Setiawan: Kebutuhan dan Faktor Kontekstual...

banyak penelitian tentang komunikasi. Karena karakteristik interaktivitas yang dimilikinya, web resmi perusahaan (organisational website) banyak digunakan untuk diseminasi informasi dan membangun hubungan antara berbagai masyarakat yang berbeda dengan organisasi (Esrock \& Leichty, 2000; Kent, Taylor, \& White,2001).

Berdasarkan Teori Kekayaan Media (MRT) terdapat empat kriteria untuk menilai media, yaitu kesegeraan (immediacy), keragaman isyarat (multiple clues), variasi bahasa (language variety), dan sumber personal (personal source) (Daft \& Lengel, 1984, 1986). Lodhia (2006) menambahkan empat kriteria lain, yaitu keragaman penerima (multiple addressibility), perekaman eksternal (externally recordable), memori terolahkan komputer (computer processable memory), dan konkurensi (concurrency).

Kesegeraan merujuk pada kemampuan media untuk menyediakan informasi secara berkala dan memungkinkan umpan balik secara cepat. Keragaman isyarat mengacu pada kemampuan untuk mengomunikasikan pesan melalui pendekatan yang berbeda-beda, seperti tubuh, bahasa, suara dan intonasi. Variasi bahasa menunjukkan kemampuan penggunaan kata yang berbeda untuk meningkatkan pemahaman, yaitu pada variasi cara dalam menyampaikan ide dan konsep melalui simbol bahasa. Sementara sumber personal memfokuskan pada kemampuan untuk menunjukkan perasaan dan emosi. Sumber personal ini penting dalam rangka penyampaian pesan kepada pengguna akhir.

Keragaman penerima merujuk pada kemampuan untuk menyampaikan pesan secara simultan kepada banyak pengguna. Kriteria perekaman eksternal berhubungan dengan kemampuan media untuk menyediakan rekaman komunikasi, termasuk kemampuan untuk mendokumentasikan (juga memodifikasi) proses komunikasi. Memori terolahkan komputer berarti bahwa informasi dapat diorganisir dan diatur secara elektronik, misalnya dapat diperoleh melalui proses pencarian. Kriteria terakhir, yakni konkurensi merujuk pada kemampuan media untuk memfasilitasi interaksi antara banyak pengguna secara simultan.

Penggunaan media oleh suatu organisasi dipengaruhi oleh kebutuhan manajemen untuk berkomunikasi. Hal ini adalah implikasi teoritis dari pandangan yang dikemukakan oleh Henderson \& Venkatraman (1993) yang mengembangkan model strategic alignment yang terintegrasi dengan strategi bisnis, infrastruktur organisasi, strategi sistem informasi, dan infrastruktur sistem informasi. Dengan demikian, apakah kekayaan suatu media, seperti dikonsepkan melalui Kerangka Kekayaan Media, digunakan dalam praktik akan tergantung pada kebutuhan manajemen untuk berkomunikasi melalui suatu media. Kebutuhan komunikasi CSR yang paling utama adalah kesegeraan, aksesibilitas, presentasi dan organisasi, dan interaksi dengan pemangku kepentingan.

Fitur Kerangka Kekayaan Media menunjukkan bahwa suatu media dapat memfasilitasi kebutuhan komunikasi CSR (Lodhia, 2006). Tabel 1 memperlihatkan hubungan antara kebutuhan komunikasi CSR dan fitur dari kerangka Kekayaan Media yang diamati. 
Harmoni, Ratih, Purwanti, dan Setiawan: Kebutuhan dan Faktor Kontekstual...

Tabel 1. Kebutuhan Komunikasi CSR dan Fitur Kerangka Kekayaan Media

\begin{tabular}{ll}
\hline Kebutuhan Komunikasi CSR & Fitur Kerangka Kekayaan Media \\
\hline Ketepatan Waktu & Kesegeraan \\
Aksesibilitas & Keragaman Penerima \\
Presentasi dan Organisasi & Keragaman Isyarat, Variasi Bahasa, Sumber \\
& Personal, Memori Terolahkan Komputer, dan \\
& Perekaman Eksternal \\
Interaksi & Konkurensi, Sumber Personal \\
\hline
\end{tabular}

\section{METODE}

Metodologi yang digunakan dalam penelitian ini adalah studi kasus. Seperti yang dikemukakan Yin (2003), studi kasus dapat dilakukan untuk penelitian yang bersifat eksplanatif. Pada penelitian ini digunakan studi dengan tiga kasus. Metode ini dipilih untuk memenuhi kebutuhan menjawab pertanyaan tentang faktor-faktor yang memengaruhi tingkat penggunaan web oleh perusahaan yang berada pada industri yang sensitif lingkungan dalam mengomunikasikan isu terkait CSR. Metode yang sama juga digunakan oleh O'Dnovan (2002). Penelitian yang dilakukan oleh Adams \& Frost (2004), Unerman \& Bennett (2004) juga menggunakan metode studi kasus untuk meneliti komunikasi lingkungan berbasis web yang difokuskan pada analisis mendalam pada perusahaan yang bergerak pada sektor tertentu.

Pemahaman yang lebih spesifik pada praktik yang berkembang pada industri tertentu adalah prioritas pada penelitian ini. Dalam penelitian ini perusahaan yang dipilih adalah perusahaan pada industri pertambangan yang beroperasi dan telah go public di Indonesia. Perusahaan pada industri pertambangan dipilih karena industri ini tergolong sensitif lingkungan dan secara langsung ditunjuk oleh Undang - Undang Perseroan Terbatas No 40 Tahun 2007. Perusahaan pada industri yang sensitif lingkungan lebih ekstensif melakukan komunikasi lingkungan dibandingkan dengan perusahaan yang tidak terlalu nampak menimbulkan dampak lingkungan.

Kriteria pemilihan perusahaan untuk penelitian ini adalah perusahaan yang termasuk dalam salah satu Indeks Bisnis-27 pada periode Nov 2011 - April 2012, dan mempunyai web yang dapat diakses. Surat dan email dikirimkan kepada perusahaan untuk meminta kesediaan wawancara dengan personel yang bertanggung jawab terhadap CSR dan/atau komunikasi perusahaan.

Data dikumpulkan melalui monitoring web, wawancara, dan analisis dokumen. Sumber bukti dari beberapa proses pengumpulan data ini memungkinkan dilakukannya triangulasi data. Monitoring dilakukan berdasarkan kerangka Kekayaan Media. Wawancara dilakukan dengan cara relatif informal berdasar pada tema kunci dan pengetahuan yang bersifat situasional dan kontekstual. Wawancara dilakukan secara semi terstruktur. Daftar pertanyaan yang sama disiapkan untuk semua perusahaan. Meski 
Harmoni, Ratih, Purwanti, dan Setiawan: Kebutuhan dan Faktor Kontekstual...

demikian, sesuai dengan praktik komunikasi yang terjadi pada masing-masing perusahaan, pertanyaan lain - yang tidak tercantum dalam daftar - dapat ditanyakan kepada responden.

Pertanyaan pada wawancara didisain untuk menangkap berbagai faktor yang memengaruhi komunikasi CSR berbasis web sebagai mana ditampilkan pada Tabel 1. Data yang diperoleh dari analisis hasil wawancara dari setiap perusahaan ditriangulasi dengan bukti yang didapat dari metode pengumpulan data lainnya, yaitu monitoring web dan bukti dokumen.

Kebutuhan komunikasi diklasifikasi sebagai kritikal atau non-kritikal untuk mengetahui penting atau tidaknya kebutuhan perusahaan untuk berkomunikasi tentang CSR melalui web. Sedangkan pemanfaatan fitur web dinilai dengan terbatas, moderat, dan ekstensif.

\section{HASIL DAN PEMBAHASAN}

Kontekstual Perusahaan. Perusahaan A adalah penghasil batubara termal di Indonesia. Mengoperasikan tambang batu bara tunggal terbesar di Indonesia, dan merupakan pemasok utama batubara termal yang ditransportasikan melalui laut ke pasar global. Perusahaan A didirikan di Indonesia sebagai perusahaan terbatas pada tahun 2004 yang kemudian berubah nama menjadi seperti yang digunakannya saat ini pada tahun 2008. Perusahaan A mempunyai visi untuk menjadi perusahaan penambangan batubara dan energi terpadu yang terbesar dan paling efisien di Asia Tenggara.

Perusahaan A mencatatkan sahamnya di Bursa Efek Indonesia pada pertengahan tahun 2008. Dengan wilayah konsesi penambangan batubara di Selatan Kalimantan, Perusahaan A melakukan aktivitas penambangan batubara melalui satu anak perusahaannya. Perusahaan A mempunyai beberapa anak perusahaan yang memungkinkannya menjadi perusahaan yang terintegrasi dari pit to port.

Konsumen Perusahaan A berada di 17 negara dan 4 benua di seluruh dunia. Lebih dari $80 \%$ dari sekitar 40 konsumennya adalah perusahaan pembangkit listrik. Dalam Laporan Keberlanjutannya dan diperkuat oleh pernyataan Responden A1, A2, dan A3, pemangku kepentingan Perusahaan A adalah pemegang saham, karyawan, kontraktor, masyarakat, LSM dan organisasi masyarakat, Perguruan Tinggi dan lembaga penelitian, pemerintah daerah, DPRD, dan media massa.

Perusahaan B didirikan sebagai Badan Usaha Milik Negara pada tahun 1968 melalui merjer beberapa perusahaan pertambangan nasional yang memproduksi komoditas tunggal. Perusahaan B mencatatkan sahamnya di Bursa Efek Indonesia dan di Australia dengan status ASX Listing.

Perusahaan B merupakan perusahaan pertambangan yang terdiversifikasi dan terintegrasi secara vertikal yang berorientasi ekspor. Melalui wilayah operasi yang tersebar di seluruh Indonesia yang kaya akan bahan mineral, kegiatan Perusahaan B 
Harmoni, Ratih, Purwanti, dan Setiawan: Kebutuhan dan Faktor Kontekstual...

mencakup eksplorasi, penambangan, pengolahan serta pemasaran dari sumber daya mineral yang dimiliki. Perusahaan B memiliki konsumen jangka panjang yang loyal di Eropa dan Asia. Perusahaan B mempunyai visi menjadi korporasi global berbasis pertambangan dengan pertumbuhan sehat dan standar kelas dunia.

Komoditas utama Perusahaan B adalah bijih nikel kadar tinggi atau saprolit, bijih nikel kadar rendah atau limonit, feronikel, emas, perak dan bauksit. Jasa utama Perusahaan B adalah pengolahan dan pemurnian logam mulia serta jasa geologi.

Perusahaan B mengidentifikasi tujuh pemangku kepentingan utama perusahaan yaitu pemegang saham, pegawai, mitra kerja, pemerintah, masyarakat, konsumen dan media. Dalam wawancara dengan Responden B1 dan B2 terungkap bahwa pemerintah dalam hal ini adalah pemerintah pusat dan daerah. Responden B1 dan B2 menyatakan bahwa pemerintah daerah, apalagi di era otonomi daerah mempunyai kekuasaan lebih besar dalam pemberian atau perpanjangan ijin usaha pertambangan, karena itu hubungan dengan pemerintah daerah menjadi sangat penting.

Perusahaan C didirikan di Indonesia pada tahun 1987 sebagai perusahaan di bidang pertambangan batubara. Perusahaan $\mathrm{C}$ mencatatkan sahamnya di BEI pada akhir tahun 2007. Dengan wilayah konsesi penambangan batubara di Provinsi Kalimantan Timur, Kalimantan Tengah, dan Kalimantan Selatan, Perusahaan C melakukan aktivitas penambangan batubara melalui 5 anak perusahaannya. Pada tahun 2009 produksi batubara tercatat mencapai 21,4 juta ton menjadikan Perusahaan $\mathrm{C}$ sebagai produsen batubara thermal ketiga di Indonesia.

Perusahaan C memfokuskan program CD-CSRnya pada memperkaya dan mengembangkan kualitas hidup masyarakat setempat. Hal ini dilakukan untuk mempertahankan penerimaan masyarakat dan goodwill serta pertumbuhan yang berkelanjutan dan keuntungan, Perusahaan $\mathrm{C}$ harus menjamin lingkungan yang kondusif untuk operasi yang berkelanjutan dan pertumbuhan. Di samping itu perusahaan harus mengembangkan ketahanan masyarakat yang berkelanjutan di wilayah sekitar operasi penambangan selama operasi dan setelahnya, untuk menjamin keberlanjutan citra perusahaan dan mitigasi risiko.

Kebutuhan Komunikasi Berbasis Web Oleh Manajemen. Ketepatan Waktu. Kebutuhan manajemen akan ketepatan waktu adalah kritikal. Wawancara dengan responden mengisyaratkan hal tersebut:

Perusahaan berkomitmen untuk mengungkapkan informasi tanpa lag khususnya dalam hubungan dengan Investor... Setelah kami menyampaikan informasi (wajib) kepada regulator, semua informasi tersebut akan kami publikasikan. Semua laporan yang sifatnya rutin dan non rutin... (Responden A1).

Hal ini dapat dilihat juga pada temuan dari analisis web yang menunjukkan tingginya penggunaan fitur kesegeraan pada web. Wawancara dengan Responden B dan C memberikan gambaran adanya kesadaran personil tentang potensi web dalam 
Harmoni, Ratih, Purwanti, dan Setiawan: Kebutuhan dan Faktor Kontekstual...

menyediakan komunikasi yang tepat waktu. Namun demikian, kebijakan untuk memberi tahu sampai pada tingkat Grup dan mendapat persetujuan Grup di kantor pusat di luar negeri sebelum dapat dirilis pada web seringkali membuat informasi tertentu membutuhkan waktu lebih lama untuk dipublikasikan. Temuan dari analisis web mendukung pernyataan tersebut, yaitu dari moderatnya penggunaan fitur kesegeraan pada web.

Kami punya kebijakan bahwa $\mathrm{H}+2$ berita (tentang kegiatan) sudah harus dipublikasi-kan... Kami ingin nanti ada semacam real time reporting... Komite (Komite CSR - LPT) ingin laporan berkelanjutan langsung diperbaharui setiap ada perubahan angka atau informasi (Responden B1).

Kami harus mendapat persetujuan dari pimpinan di Grup untuk informasi tertentu... tapi setidaknya kami usahakan satu atau dua minggu (untuk bisa ditampilkan pada web) (Responden C).

Presentasi dan Organisasi. Penggunaan kemampuan organisasi cukup ekstensif tetapi presentasi tidak terlalu ekstensif digunakan. Responden A1 menekankan bahwa walaupun perusahaan menyadari pentingnya web sebagai sarana komunikasi, Perusahaan A tidak menggunakan animasi atau multimedia dalam menyampaikan informasi melalui web. Responden A1 mengindikasikan bahwa pengunjung yang lebih banyak menggunakan web adalah para analis dan manajer keuangan sehingga informasi yang disampaikan dan bentuk informasi disesuaikan dengan kebutuhan pemangku kepentingan tersebut. Hal ini juga sesuai dengan keterangan Responden A1 yang menyatakan bahwa web perusahaan dikelola oleh Hubungan Investor. Sementara Responden B3 menekankan bahwa hal terbatasnya fitur presentasi dilakukan agar pengunjung web lebih mudah dan lebih cepat mengakses informasi.

Informasi yang disampaikan adalah disclosure yang wajib kami sampaikan kepada regulator (Responden A1).

Mula-mula kami memang menampilkan video (tentang pengolahan produk) tapi bandwidth terbatas, kalau dibuka jadi lambat sekali sehingga akhirnya kami buang semua potongan videonya, kami pakai gambar-gambar saja. ... Jadi yang penting informasinya dan kalau perlu ditampilkan gambar.

(Responden B3).

"Pemilik" web adalah Hubungan Investor karena yang paling banyak mengakses adalah para analis (Responden A1).

Pada wawancara dengan Responden A2 diperoleh pernyataan bahwa web adalah salah satu media yang penting untuk menjelaskan "apa dan siapa" Perusahaan A:

Web penting terutama untuk publik agar mereka tahu Perusahaan A itu apa?

Siapa? Web penting terkait dengan performance Perusahaan A itu sendiri. 
Harmoni, Ratih, Purwanti, dan Setiawan: Kebutuhan dan Faktor Kontekstual...

(Responden A2).

Perusahaan $\mathrm{C}$ tidak menyampaikan informasi secara rinci melalui web. Responden $\mathrm{C}$ menyampaikan bahwa web lebih ditujukan kepada pemangku kepentingan umum daripada pemangku kepentingan tertentu.

Informasi yang kami sampaikan lebih bersifat general (Responden C).

Perusahaan sangat hati-hati dalam menyampaikan informasi. Hal ini juga terkait dengan kebijakan Grup secara keseluruhan. Walau pun demikian Responden C menyatakan bahwa perusahaan tidak menutup kemungkinan untuk memberikan informasi yang lebih rinci pada pemangku kepentingan yang berminat melalui cara lain.

Kami punya website, buletin, forum, dan lain-lain (untuk berkomunikasi)... Kebutuhan informasi yang berbeda bagi pemangku kepentingan yang berbeda. Misalnya akademik atau LSM tentu berbeda. (Mereka) bisa menghubungi kami (Responden C).

Responden B3 mengisyaratkan bahwa pada masa yang akan datang presentasi dan organisasi akan terus ditingkatkan.

Kami ingin lebih interaktif. Sekarang, untuk membaca atau mengambil data (laporan) pengunjung harus download dulu... kami ingin seperti Annual Report yang sekarang sudah interaktif, dibuat per seksi... Ekonomi sendiri, sosial sendiri... lingkungan sendiri. Khusus untuk kinerja CSR (Responden B3).

Saat ini, web portal khusus CSR belum ada tetapi Responden A1 menyebutkan web yang sudah ada sebelumnya yang dimiliki oleh salah satu anak perusahaan dari Perusahaan A. Web ini sampai saat ini masih dapat diakses. Pada web tersebut program CSR dari anak perusahaan juga dapat dibaca. Sebuah tautan ke web portal tentang Pengembangan Masyarakat (Community Development) terdapat pada web ini. Responden A1 lebih lanjut menjelaskan bahwa untuk mencapai tujuan penyampaian informasi CSR, Perusahaan A juga memanfaatkan web komersial dari harian nasional yang ada yang mempunyai rubrik CSR.

... (agar) tujuan penyampaian informasi bisa tercapai, kami memanfaatkan juga website (dari dot com) yang lain. Media adalah perpanjangan dari kami. Jadi walau pun kami mengoptimalkan (web kami) tapi (pembaca) umum banyak juga yang mencari lewat media yang komersial (Responden A1)

Sesuai dengan analisis web umum dan longitudinal yang dilakukan pada web Perusahaan A, apa yang disampaikan oleh Responden A1 menjelaskan terbatasnya penggunaan fitur ragam isyarat, tetapi lebih banyak memanfaatkan fitur sumber personal, variasi bahasa, perekaman eksternal, dan memori terolahkan komputer pada web perusahaan. Sedangkan dari web Perusahaan B, apa yang disampaikan oleh 
Harmoni, Ratih, Purwanti, dan Setiawan: Kebutuhan dan Faktor Kontekstual...

Responden B3 menjelaskan masih terbatasnya penggunaan fitur ragam isyarat, tetapi lebih banyak memanfaatkan fitur sumber personal, variasi bahasa, perekaman eksternal, dan memori terolahkan komputer pada web perusahaan. Sementara web Perusahaan C menunjukkan apa yang disampaikan oleh Responden $\mathrm{C}$ menjelaskan terbatasnya penggunaan fitur ragam isyarat dan moderatnya penggunaan fitur sumber personal, variasi bahasa, perekaman eksternal, dan memori terolahkan komputer pada web perusahaan.

Aksesibilitas. Aspek aksesibilitas oleh seluruh pemangku kepentingan dari komunikasi berbasis web dan jangkauan global web merupakan hal yang penting. Responden A1 menyampaikan perlunya mengomunikasikan capaian dan aktivitas perusahaan kepada seluruh pemangku kepentingan, termasuk kepada para investor asing. Responden B3 dan Responde C menyatakan hal yang senada.

Perusahaan mempunyai kebijakan untuk hanya mempublikasikan yang memang diwajibkan dan informasi lain yang perlu. Cukup informatif. Tidak berlebihan. (Responden A1).

Ada kebijakan bahwa semua yang akan dipublikasikan, baik itu di web atau di media cetak atau di media manapun itu adalah public information. Jadi kita sudah punya aturan dasarnya. Yang harus dipublish di web itu memang yang aman, sifatnya public information (Responden B3).

...apa yang kami lakukan memang perlu dishare. Siapa saja yang berkepentingan dengan perusahaan dapat membaca apa yang ada di web (Responden C).

Pernyataan Responden A1 mengindikasikan bahwa semua informasi pada web sudah dipertimbangkan untuk dapat dibaca oleh semua pengunjung sehingga tidak diperlukan kata kunci untuk mendapatkan informasi yang ada. Responden B2 menyatakan bahwa semua informasi yang dikeluarkan perusahaan sudah mendapat persetujuan pimpinan dan layak disampaikan ke publik. Responden C menyampaikan perlunya mengomunikasikan capaian perusahaan. Hal ini memperkuat temuan dari analisis web bahwa fitur keragaman penerima digunakan secara ekstensif oleh Perusahaan A, B, maupun C.

Interaksi. Responden A1 dan Responden B3 menyinggung tentang peran web sebagai sarana untuk berinteraksi dengan pemangku kepentingan. Komunikasi melalui surel membantu dalam berinteraksi dengan pemangku kepentingan. Pemangku kepentingan bisa mendapatkan email alert apabila ada informasi terbaru dimuat pada web. Sebuah polling dilakukan apabila diperlukan (ad hoc) untuk menggali informasi atau mendapatkan umpan balik dari pemangku kepentingan.

Untuk teman-teman di media kami selalu memberi tahu apabila ada press release baru. Jadi selain mengandalkan telepon dan sms, kami juga kirim email. Dengan 
Harmoni, Ratih, Purwanti, dan Setiawan: Kebutuhan dan Faktor Kontekstual...

stakeholder lain juga seperti itu. Dengan Pemda setempat, tidak hanya yang terkait dengan update di web. Untuk para analis, teman-teman dari bagian IR tidak hanya mengandalkan news alert sajatapi juga punya kumpulan jaringan email yang langsung akan dikontak. Push dan pull kita kerjakan (Responden B3).

Sempat terpikir untuk mendeteksi (siapa) yang mengakses web dan bagaimana mengaksesnya. Perusahaan melakukan survey pengunjung (monkey survey) untuk mendapatkan respon dan tanggapan dan bagaimana meningkatkan (program) yang sudah ada (Reponden A1).

Pernyataan tersebut menunjukkan bahwa ada kesadaran akan pentingnya web sebagai media untuk menyampaikan informasi dan sekaligus mendapatkan umpan balik. Hasil analisis longitudinal web menunjukkan bahwa terdapat polling yang dapat diisi oleh pengunjung web. Polling tersebut berjudul Survey Persepsi Tahunan terhadap Perusahaan A. Survey Persepsi dibuat untuk mengetahui pendapat masyarakat mengenai Perusahaan A dalam kedudukannya sebagai suatu perusahaan. Secara umum, pada Perusahaan A, kebutuhan interaksi melalui web untuk informasi CSR cukup besar. Sedangkan Responden B1 dan B2 menyatakan bahwa masukan dari pengunjung web (tentang program CSR) tidak banyak dan sifatnya lebih berupa pertanyaan. Interaksi dengan media lain dan pertemuan langsung tetap dilakukan. Tabel 2 merangkum semua dampak kebutuhan komunikasi CSR oleh manajemen terhadap tingkat penggunaan web pada Perusahaan yang diteliti.

Pengaruh Kontekstual. Kebutuhan manajemen untuk berkomunikasi melalui media web dipengaruhi oleh faktor kontekstual. Faktor kontekstual tersebut dapat berupa keterbatasan teknologi, faktor ekonomi, faktor internal organisasi, dan faktor pemangku kepentingan eksternal.

Tabel 3 berikut merangkum semua faktor kontekstual yang memengaruhi praktik komunikasi CSR berbasis web pada Perusahaan A, B, dan C. Keterbatasan Teknologi mendukung kebutuhan atas ketepatan waktu dan interaksi, organisasi, dan aksesibilitas. Faktor ekonomi tidak terlalu memberikan dampak pada penggunaan media web. Faktor internal organisasi memengaruhi tingkat kebutuhan manajemen untuk mengomunikasikan informasi CSR melalui web dan berdampak pada aksesibilitas dan organisasi. Sementara itu faktor pemangku kepentingan eksternal mendorong penggunaan aksesibilitas dan organisasi tetapi membatasi penggunaan presentasi. 
Harmoni, Ratih, Purwanti, dan Setiawan: Kebutuhan dan Faktor Kontekstual...

Tabel 2. Dampak Kebutuhan Komunikasi CSR Manajemen terhadap Tingkat Penggunaan Web

\begin{tabular}{|c|c|c|c|}
\hline Kebutuhan Komunikasi & \multicolumn{3}{|c|}{ Tingkat Penggunaan Web } \\
\hline & Perugahaan A & Perusahaan B & Perugahaan C \\
\hline Ketepatan Waktu & $\begin{array}{l}\text { Kebutuhan kritikal. } \\
\text { Penggunaan fitur } \\
\text { kegegeraan ekstensif }\end{array}$ & $\begin{array}{l}\text { Kebutuhan } \\
\text { kritikal. } \\
\text { Penggunaan fitur } \\
\text { kegegeraan } \\
\text { moderat }\end{array}$ & $\begin{array}{l}\text { Kebutuhan kritikal. } \\
\text { Penggunaan fitur } \\
\text { kegegeraan moderat }\end{array}$ \\
\hline Presentasi dan Organisasi & $\begin{array}{l}\text { Terdapat variasi } \\
\text { kebutuhan pada fitur } \\
\text { tertentu. } \\
\text { Fitur perekaman } \\
\text { eksternal, sumber } \\
\text { personal, dan variasi } \\
\text { bahasa moderat } \\
\text { tetapi ragam isyarat } \\
\text { terbatas }\end{array}$ & $\begin{array}{l}\text { Terdapat variasi } \\
\text { kebutuhan pada } \\
\text { fitur tertentu. } \\
\text { Fitur perekaman } \\
\text { eksternal, sumber } \\
\text { personal, dan } \\
\text { variasi bahasa } \\
\text { moderat tetapi } \\
\text { ragam isyarat } \\
\text { terbatas }\end{array}$ & $\begin{array}{lr}\text { Terdapat } & \text { variasi } \\
\text { kebutuhan pada fitur } \\
\text { tertentu. } \\
\text { perekaman eksternal, } \\
\text { sumber personal, dan } \\
\text { variasi r bahasa } \\
\text { moderat, ragam } \\
\text { isyarat sangat terbatas }\end{array}$ \\
\hline Aksesibilitas & $\begin{array}{l}\text { Faktor kritikal. Fitur } \\
\text { keragaman penerima } \\
\text { ekstensif. }\end{array}$ & $\begin{array}{l}\text { Faktor kritikal. } \\
\text { Fitur } \\
\text { keragaman } \\
\text { penerima } \\
\text { ekstensif. }\end{array}$ & $\begin{array}{l}\text { Faktor kritikal. Fitur } \\
\text { keragaman penerima } \\
\text { ekstensif. }\end{array}$ \\
\hline Interaksi & $\begin{array}{l}\text { Kebutuhan kritikal. } \\
\text { Penggunaan sumber } \\
\text { personal ekstensif. } \\
\text { Fitur konkurensi } \\
\text { menyediakan surel } \\
\text { dan email alert, gerta } \\
\text { survey elektronik. } \\
\text { Alat analisis lain, } \\
\text { seperti forum } \\
\text { diskusi, ruang obrol, } \\
\text { dan bulletin boards } \\
\text { tidak digunakan. }\end{array}$ & $\begin{array}{l}\text { Kebutuhan } \\
\text { kritikal. } \\
\text { Penggunaan } \\
\text { sumber personal } \\
\text { ekstensif dan fitur } \\
\text { konkurensi } \\
\text { menyediakan surel } \\
\text { dan news alert. } \\
\text { Alat analisis yang } \\
\text { lain, seperti forum } \\
\text { diskusi, ruang } \\
\text { obrol, dan bulletin } \\
\text { boards tidak } \\
\text { digunakan }\end{array}$ & $\begin{array}{lr}\text { Kebutuhan } & \text { non } \\
\text { kritikal. Penggunaan } \\
\text { sumber personal } \\
\text { moderat. Fitur } \\
\text { konkurensi terbatas, } \\
\text { hanya menyediakan } \\
\text { surel dan lembar } \\
\text { umpan } \\
\text { balik. Alat analisis lain, } \\
\text { seperti forum diskusi, } \\
\text { ruang obrol, dan bulletin } \\
\text { boards tidak digunakan. }\end{array}$ \\
\hline
\end{tabular}


Tabel 3. Pengaruh Faktor Kontekstual pada Komunikasi CSR Berbasis Web pada Perusahaan

\begin{tabular}{|c|c|c|c|}
\hline \multirow[t]{2}{*}{ Pengaruh Kontekstual } & \multicolumn{3}{|c|}{ Praktik Komunikasi CSR Berbasis Web } \\
\hline & Perusahaan A & Perusahaan B & Perusahaan C \\
\hline $\begin{array}{l}\text { Keterbatasan } \\
\text { Teknologi }\end{array}$ & $\begin{array}{l}\text { Keamanan dan promosi } \\
\text { ditangani dengan baik, begitu } \\
\text { juga dengan kemelimpahan } \\
\text { informasi. Otentifikasi } \\
\text { informasi terbatas pada web } \\
\text { ComDev. }\end{array}$ & $\begin{array}{l}\text { Keamanan dan promosi } \\
\text { ditangani dengan baik, } \\
\text { begitu juga dengan } \\
\text { kemelimpahan } \\
\text { informasi. Otentifikasi } \\
\text { informasi terbatas pada } \\
\text { laporan cetakan }\end{array}$ & $\begin{array}{l}\text { Keamanan dan promosi } \\
\text { ditangani dengan baik, } \\
\text { begitu juga dengan } \\
\text { kemelimpahan } \\
\text { informasi. Otentifikasi } \\
\text { informasi pada web } \\
\text { tidak ada. }\end{array}$ \\
\hline Faktor Ekonomi & $\begin{array}{l}\text { Faktor ekonomi tidak menjadi } \\
\text { pertimbangan dalam arti web } \\
\text { dan media lain tetap dilakukan }\end{array}$ & $\begin{array}{l}\text { Faktor ekonomi } \\
\text { menjadi pertimbangan } \\
\text { dalam presentasi web. } \\
\text { Media komunikasi lain } \\
\text { tetap digunakan }\end{array}$ & $\begin{array}{l}\text { Manajemen memilih } \\
\text { untuk "Low Profile" } \\
\text { menyebabkan } \\
\text { terbatasnya informasi } \\
\text { yang dipublikasikan } \\
\text { melalui web dan } \\
\text { penggunaan web } \\
\text { sebagai media } \\
\text { komunikasi }\end{array}$ \\
\hline $\begin{array}{l}\text { Faktor Internal } \\
\text { Organisasi }\end{array}$ & $\begin{array}{l}\text { Manajemen menganggap web } \\
\text { sebagai salah satu media yang } \\
\text { penting dalam memberikan } \\
\text { informasi tentang perusahaan }\end{array}$ & $\begin{array}{l}\text { Manajemen } \\
\text { menganggap web } \\
\text { sebagai salah satu } \\
\text { media yang penting } \\
\text { dalam memberikan } \\
\text { informasi tentang } \\
\text { perusahaan }\end{array}$ & $\begin{array}{l}\text { Manajemen memilih } \\
\text { untuk "Low Profile" } \\
\text { menyebabkan } \\
\text { terbatasnya informasi } \\
\text { yang dipublikasikan } \\
\text { melalui web dan } \\
\text { penggunaan web sebagai } \\
\text { media komunikasi }\end{array}$ \\
\hline $\begin{array}{l}\text { Pengaruh } \\
\text { Pemangku } \\
\text { Kepentingan } \\
\text { Eksternal }\end{array}$ & $\begin{array}{l}\text { Perusahaan memperhatikan } \\
\text { preferensi dan kompetensi } \\
\text { pemangku kepentingan dalam } \\
\text { memperoleh informasi. } \\
\text { Penggunaan media web cukup } \\
\text { luas dan dipandang sebagai } \\
\text { kebutuhan yang tinggi }\end{array}$ & $\begin{array}{l}\text { Perusahaan } \\
\text { memperhatikan } \\
\text { preferensi dan } \\
\text { kompetensi pemangku } \\
\text { kepentingan dalam } \\
\text { memperoleh informasi. } \\
\text { Penggunaan media web } \\
\text { cukup luas dan } \\
\text { dipandang sebagai } \\
\text { kebutuhan yang tinggi }\end{array}$ & $\begin{array}{l}\text { Perusahaan } \\
\text { memperhatikan } \\
\text { preferensi pemangku } \\
\text { kepentingan dalam } \\
\text { memperoleh } \\
\text { informasi. } \\
\text { Penggunaan media web } \\
\text { tidak terlalu luas. }\end{array}$ \\
\hline
\end{tabular}

Perlu Tahu. Dalam wawancara dengan Responden terungkap faktor yang menjadi pertimbangan manajemen dalam mengomunikasikan program CSR melalui web. Responden A2 dalam pernyataannya mengungkapkan:

Sebetulnya kami lebih suka mengerjakan program saja.Tetapi ada Corporate

Secretary yang perlu menyampaikan pada publik karena (CSR) dinilai oleh masyarakat sebagai kinerja perusahaan (Responden A2).

Pernyataan tersebut mengindikasikan bahwa perusahaan lebih mementingkan mengerjakan program CSR tanpa pemberitaan berlebihan. Filosofi "Tangan kanan memberi, tangan kiri tidak perlu tahu" menjadi pertimbangan. Sejumlah isu mungkin 
perlu disampaikan pada web sementara beberapa lainnya mungkin tidak diperlukan. Pendapat ini juga memengaruhi presentasi pada web.

... Secara tidak langsung tanpa dinyatakan atau dijabarkan (program CSR) itu sudah terjadi. Kami mempunyai konsesi untuk melakukan penambangan, untuk bisa operasi perlu dukungan dari masyarakat dan pemerintah. Tanpa memberi sesuatu yang nyata untuk mereka sekarang dan masa depan, support mereka tidak sebagus sekarang. Hubungan dengan pemda sangat bagus. Karena mereka tahu kita memberi sesuatu. Nah, itu tidak dinyatakan secara eksplisit.... (Responden A2).

... sebetulnya kalau kita berbuat baik dengan tangan kanan, tangan kiri tidak perlu tahu... karena kami juga harus waspada dengan pemberitaan yang mungkin berlebihan. ... yang penting adalah bagaimana kami berkontribusi di masyarakat dari waktu ke waktu (Responden C).

Pernyataan tersebut menyiratkan bahwa perusahaan mempunyai pandangan bahwa tidak semua kegiatan harus disampaikan walaupun dalam beberapa hal, beberapa kegiatan diantaranya penting untuk membangun citra perusahaan. Sejumlah isu mungkin tidak tepat untuk ditempatkan pada web karena bisa dianggap berlebihan dan hanya untuk kepentingan iklan. Pada satu sisi perusahaan harus berusaha untuk menampilkan kinerja yang baik dalam kegiatan CSR tetapi komunikasi yang berlebihan akan sama berbahayanya bagi perusahaan. Ada kecenderungan pemangku kepentingan untuk mempertanyakan apa yang disampaikan oleh perusahaan tentang kegiatannya sendiri. Faktor "tangan kanan memberi, tangan kiri tidak perlu tahu" dalam beberapa hal membatasi presentasi informasi pada web.

Sementara dalam wawancara dengan Responden B1 terungkap pernyataan:

Dulu Perusahaan kalau memberi tidak perlu bicara kemana-mana. Istilahnya “tangan kanan memberi tangan kiri tidak perlu tahu”. Tapi tidak semua orang bisa melihat bahwa kami sudah berbuat, masih ada yang curiga, makanya sekarang tangan kanan memberi, tangan kiri harus tahu. Itu sebabnya di pusat ada Corsec, di unit ada External Relation. Mereka yang berfungsi untuk bicara dengan media. Jadi kami memang sudah harus bicara. Tidak tanggung-tanggung kalau sifatnya monumental kita muat di koran, di tv ... Termasuk di website (Responden B1).

Pernyataan tersebut mengindikasikan bahwa pandangan "Tangan kanan memberi, tangan kiri tidak perlu tahu" pernah menjadi pertimbangan dalam mengomunikasikan program. Sejumlah isu mungkin perlu disampaikan pada web sementara beberapa lainnya mungkin tidak diperlukan. Pendapat ini juga memengaruhi presentasi pada web. Dalam perkembangan selanjutnya, Perusahaan mempertimbangkan lebih banyak mengungkapkan program yang telah dilakukannya kepada pemangku kepentingan. Lebih lanjut Responden B2 mengungkapkan, walaupun Comdev melaporkan semua programnya kepada Corsec, pengungkapan tetap dipertimbangkan skalanya. 
Harmoni, Ratih, Purwanti, dan Setiawan: Kebutuhan dan Faktor Kontekstual...

Untuk media nasional dan web, Corsec yang akan menilai urgensinya karena kami harus mempertimbangkan bagaimana program ini, bagus atau tidak... sebanding tidak dengan apa yang kami harapkan dengan melakukan publikasi... Itu dilakukan oleh Corsec. Kami punya one gate policy. Corsec yang boleh bicara... ada uji materialitas. Tidak hanya dari segi dananya tapi juga dari segi dampaknya (Responden B2).

Dengan pernyataan tersebut dapat dikatakan bahwa tetap ada kebijakan tentang program dan capaian yang diperoleh perusahaan dalam CSR pada webnya. Responden C lebih lanjut menyatakan:

... supaya masyarakat juga tahu dan kami menyampaikan itu sebenarnya yang semuanya sudah terjadi, bukan yang akan terjadi (Responden C).

Dalam praktik, perusahaan harus menyeimbangkan antara apa yang dilakukan dan bagaimana komunikasi yang tepat pada webnya. Perusahaan B menggunakan media lain sebagai sarana komunikasi untuk isu tertentu pada pemangku kepentingan tertentu dengan tetap memberi uraian singkat pada webnya.

Pengaruh Kebutuhan dan Faktor Kontekstual Komunikasi CSR berbasis Web. Perusahaan $\mathrm{A}, \mathrm{B}$, dan $\mathrm{C}$ menggunakan web sebagai sarana menyampaikan informasi secara umum dan sebagai pelengkap komunikasi CSR melalui laporan cetakan dan media lainnya.

Web Perusahaan A dan B menggunakan fitur keragaman penerima secara ekstensif, sedangkan fitur ketepatan waktu, variasi bahasa, sumber personal, perekaman eksternal, memori terolahkan computer, dan konkurensi digunakan secara moderat. Fitur ragam isyarat digunakan secara terbatas. Web Perusahaan $\mathrm{C}$ menggunakan fitur keragaman penerima secara ekstensif dan fitur kesegeraan, perekaman eksternal, variasi bahasa, sumber personal, dan memori terolahkan komputer secara moderat. Sedangkan fitur ragam isyarat dan konkurensi digunakan secara terbatas.

Pada Perusahaan A, kebutuhan manajemen atas komunikasi CSR berbasis web terutama adalah ketepatan waktu, organisasi, aksesibilitas dan interaksi. Hal ini didukung oleh batasan teknologi, pandangan manajemen dan faktor pemangku kepentingan. Pada saat yang sama faktor tersebut juga membatasi penggunaan web. Pertimbangan "tangan kanan memberi, tangan kiri tidak perlu tahu" juga membatasi kebutuhan untuk presentasi pada web.

Pada Perusahaan B, kebutuhan manajemen atas komunikasi CSR berbasis web terutama adalah ketepatan waktu, organisasi, aksesibilitas dan interaksi. Hal ini didukung oleh batasan teknologi, faktor ekonomi, pandangan manajemen dan faktor pemangku kepentingan eksternal. Pada saat yang sama faktor tersebut juga membatasi penggunaan web. Pertimbangan "tangan kanan memberi, tangan kiri tidak perlu tahu" sudah mulai ditinggalkan karena perusahaan menganggap bahwa program CSR penting untuk 
menjaga reputasi perusaaan dan mendapatkan social license to operate dari pemangku kepentingan.

Pada Perusahaan C, kebutuhan manajemen atas komunikasi CSR berbasis web terutama adalah organisasi dan aksesibilitas. Hal ini didukung oleh pandangan manajemen. Kebutuhan dan preferensi pemangku kepentingan menyebabkan terbatasnya penggunaan presentasi dan interaksi. Pertimbangan stratejik perusahaan dan pandangan "tangan kanan memberi, tangan kiri tidak perlu tahu" juga membatasi kebutuhan untuk presentasi dan interaksi.

\section{PENUTUP}

Simpulan. Kebutuhan manajemen atas komunikasi CSR berbasis web yang kritikal atau non-kritikal memengaruhi tingkat penggunaan fitur web yang sesuai. Kebutuhan komunikasi yang dianggap kritikal akan menyebabkan pemakaian fitur web ekstensif atau moderat dan sebaliknya apabila manajemen menganggap kebutuhan komunikasi berbasis web adalah non-kritikal maka penggunaan fitur web terbatas. Tingkat penggunaan web sebagai media komunikasi CSR juga dipengaruhi oleh faktor kontekstual yaitu teknologi, ekonomi, internal organisasi (pandangan manajemen), dan pemangku kepentingan eksternal. "Tangan kanan memberi, tangan kiri tidak perlu tahu" adalah pandangan yang ikut dipertimbangkan dalam pengungkapan informasi CSR melalui web.

Penelitian ini terbatas pada tiga perusahaan tambang yang beroperasi di Indonesia. Penelitian yang lebih luas dengan perusahaan tambang yang lebih banyak bisa memberikan gambaran yang lebih lengkap tentang kebutuhan komunikasi CSR berbasis web. Penelitian berikutnya juga dapat dilakukan dari sisi pemangku kepentingan yang memanfaatkan web perusahaan.

\section{DAFTAR RUJUKAN}

Adams, C.A. and Frost, G.R. (2004). The development of corporate website and implivations for ethical, social, and environmental Reportig through these media. The Institute of Chartered Accountants of Scotland, Edinburgh

Almalia, Luciana Spica. (2009). Analisa Kualitas Isi Finansial and Sustainability Reporting pada Website Perusahaan Go Publik di Indonesia. Prosiding Seminar Nasional Aplikasi Teknologi Informasi 2009 (SNATI 2009), Yogyakarta, pp, B-34B-38

Campbell, D.J. (2004). “A longitudinal and cross-sectional analysis of environmental disclosure in UK companies - a research note", British Accounting Review, 36 (1), 107-117

Cormier, D., M. Magnan. (2003). "Environmental reporting management: A European perspective". J. Acctg. Pub. 22 (1), 43-62

Daft, R. and R. Lengel, (1984). "Information richness: a new approach to managerial behaviour and organization Design”, Research in Organizational Behaviour, 6, 191- 
Harmoni, Ratih, Purwanti, dan Setiawan: Kebutuhan dan Faktor Kontekstual...

233

(1986). "Organizational Information Requirements, Media Richness and Structural Design", Management Science, 32 (5), 554-571

Esrock, S. and Leicthty, G. (1998). "Social Responsibility and Web Pages: Self Presentation or Agenda Setting?", Public Relation Review, 24(3), 305-319 (2000). "Organization of Corporate web pages: Publics and Functions". Public Relation Review, 26(3), 327-344

Frost, G., Jones, S., Loftus, J., and Van Der Laan, S. (2005). “A Survey of Sustainability Reporting Practices of Australian Reporting Entities". Australian Accounting Review, 15 (1), 89-97

Harmoni, Ati. (2011). "Management's Need for Web Based CSR Communication: Application of Media Richness Theory". Jurnal Ilmiah Ekonomi Bisnis, 16 (3)

(2010). "Pemanfaatan Laman Resmi sebagai Media Pengungkapan Tanggung Jawab Sosial Perusahaan/CSR pada Perusahaan di Indonesia”. Jurnal Ilmiah Ekonomi Bisnis. 1 (15)

( 2009). “Interaktivitas Isu CSR pada Laman Resmi Perusahaan. Studi pada PT Indocement Tunggal Prakarsa Tbk". Prosiding Seminar Nsional Teknologi Informasi, (SNATi). FTI - UII. Yogyakarta.

Henderson, J.C., \& Venkatraman, N. (1993). "Strategic Alignment: Leveraging Information Technology for transforming organizations". IBM Systems Journal. 32 (1), 4-16

Kent, M.L., M. Taylor, W.J. White. (2001). "How activist organizations are using the internet to build relationships". Pub. Rel. Rev. 27(3), 263-284

Lodhia, Sumit K., (2006). "The World Wide Web and its potential for corporate environmental communication: a study into present practices in the Australian minerals industry", The Inernational Journal of Digital Accounting Research, 6 (11), 65-94,

Maignan, I., Ralston, D.A. (2002). "Corporate Social Responsibility in Europe and the U.S.: Insights from Businesses' Self-Presentations". Journal of International Business Studies, Volume 33

O'Donovan, G. (2002). "Environmental Disclosures in the annual report: extending the applicability and predictive power of legitimacy theory". Accounting, Auditing, and Accountability Journal, 15 (3), 344-371

SustainAbility/UNEP. (2001). Virtual Sustainability. Engaging Stakeholder Series. Sustain Ability/UNEP, London.

.(2004). Risk and Opportunity: Best practice in Non-Financial Reporting. SustainAbility/Standards and Poor's/UNEP, London

Unerman, J. and Bennet, M. (2004). "Increased stakeholder dialogue and the Internet: towards greater corporate accountability or reinforcing capitalist hegemony? Accounting", Organisations and Society, 29 (7), 685-707.

Yin, R.K. (2003). Case Study Research: Design and Methods. $3^{\text {rd }}$ edition. Sage Publications. London. 